
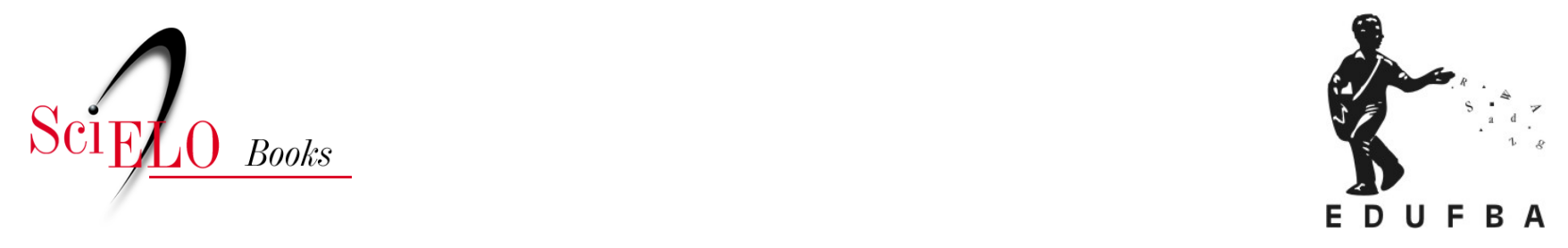

\title{
A prática de preservação urbana nos anos 1990
}

\author{
Marcia Sant'Anna
}

\section{SciELO Books / SciELO Livros / SciELO Libros}

SANT'ANNA, M. A prática de preservação urbana nos anos 1990. In: A cidade-atração: a norma de preservação de áreas centrais no Brasil dos anos 1990 [online]. Salvador: EDUFBA-PPG-AU FAUFBA, 2017, pp. 349-393. ISBN: 978-85-232-1871-3.

https://doi.org/10.7476/9788523218713.0010.

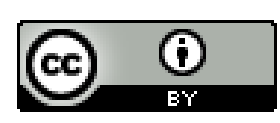

All the contents of this work, except where otherwise noted, is licensed under a Creative Commons Attribution $\underline{4.0 \text { International license. }}$

Todo o conteúdo deste trabalho, exceto quando houver ressalva, é publicado sob a licença Creative Commons Atribição 4.0. 


\section{A prática de preservação urbana nos anos 1990}

\section{Considerações preliminares}

Este capítulo encerra dois objetivos principais. O primeiro é cotejar e comparar as intervenções de revitalização, requalificação e reabilitação executadas nas áreas centrais de Salvador, Rio de Janeiro e São Paulo durante os anos 1990, com vistas a identificar suas especificidades e características comuns. O outro é fazer o mesmo em relação aos programas nacionais de preservação implantados naquela década, identificando suas convergências e divergências, seus inter-relacionamentos e seus vínculos com as intervenções nas cidades selecionadas, avaliando-se os modelos de intervenção que buscaram implantar e os resultados que alcançaram.

As intervenções locais são aqui analisadas a partir: (1) de sua vinculação com experiências anteriores, em termos de continuidade ou rompimento; (2) da influência que sofreram da história urbana, do planejamento urbano e das políticas de preservação do patrimônio; (3) dos seus objetivos e metas; (4) das áreas que atingiram; (5) da natureza e do tipo de trabalho executado; e(6) dos modelos de intervenção e gestão que construíram e seus 
resultados. São ainda identificadas e comentadas as características gerais dos mecanismos financeiros, legais, urbanísticos e de gestão que foram utilizados.

A compreensão da dinâmica urbana, social e econômica das cidades surgiu também como essencial à análise das intervenções, uma vez que estas tiveram por objetivos, mais do que conservar o patrimônio, reverter processos de esvaziamento e deslocamento de funções, atrair novos consumidores e investimentos, promover a renovação de usos e valorizar o setor em foco e seu parque imobiliário. Assim, a avaliação dos resultados dessas intervenções vinculou-se também ao grau de efetividade que apresentaram como instrumentos de potencialização e de transformação de processos instalados.

Os programas nacionais de preservação foram, por sua vez, abordados a partir dos mesmos eixos de análise utilizados no estudo comparativo das intervenções locais, com os objetivos de avaliar sua efetividade como instrumentos de preservação e de reunir evidências sobre a adoção e a influência de padrões estrangeiros na formulação de políticas de preservação no Brasil, bem como na reestruturação do aparato institucional vinculado ao patrimônio. Por fim, avalia-se o papel de organismos internacionais e multilaterais na prática preservacionista desenvolvida durante o período estudado.

\section{Os solos históricos das intervenções nas áreas centrais de Salvador, Rio de Janeiro e São Paulo}

Salvador, Rio de Janeiro e São Paulo, as três cidades mais populosas do Brasil nos anos 1990, têm suas histórias políticas e econômicas entrelaçadas. Fundadas no século XVI, elas foram, pela ordem, como num jogo de passar a bola (e ao sabor das conveniências, oportunidades e circunstâncias políticas e econômicas que pontuaram o desenvolvimento brasileiro), sucessivamente alçadas à condição de maior centro urbano do país. Cada deslocamento de centralidade no plano nacional implicou o esvaziamento e a estagnação de um polo e de sua região, e o crescimento e a dinamização de outro, em processos que, embora de intensidades e durações diversas, imprimiram marcas profundas no desenvolvimento de cada uma das cidades enfocadas. Esses processos influenciaram as decisões políticas e de planejamento que configuraram o que se poderia chamar de "parque 
patrimonial" de cada uma delas, bem como os contornos das políticas de preservação traçadas ao longo do século XX. Os pesos políticos e econômicos diversos de cada uma dessas cidades ensejaram, até os anos 1970, distintas trajetórias de preservação urbana, as quais, ainda que regidas por uma ideia de patrimônio comum, se relacionaram diretamente com as demandas de renovação e expansão de suas áreas centrais e com os constrangimentos colocados por cada acervo patrimonial a esses processos.

A história da modernização urbana e da preservação do patrimônio nas áreas centrais dessas três capitais mostra que, em cada uma delas, esses processos tiveram características comuns e particularidades. Em primeiro lugar, observa-se que a preservação do patrimônio, longe de constituir um ato de resistência, buscou amoldar-se à modernização ou, como ocorreu de modo inaugural em Salvador, atuou preferencialmente em suas "sobras", ou seja, nas áreas não demandadas por essa dinâmica. Preservação e modernização urbana no Brasil foram, na realidade, processos complementares. Em Salvador e no Rio de Janeiro, o "parque patrimonial" existente nas respectivas áreas centrais é resultado da interaçãa e da negociação entre as forças da preservaçãao e as da transformação e, principalmente, da falta de fôlego da dinâmica modernizadora para penetrar em certas áreas que, assim, puderam ir sendo integralmente incorporadas ao patrimônio. Em São Paulo, de modo diverso, o acervo urbano tardiamente preservado foi produto apenas desse segundo fenômeno, correspondendo ao que sobreviveu a mais de um século de reconstruções e substituições.

Nas três cidades, as disposições de proteção do patrimônio incidentes na área central foram ampliadas nos anos 1980, quando a estagnação econômica, o esvaziamento populacional e o deslocamento de funções já estavam instalados. Portanto, quando as pressões de substituição e renovação já eram fracas ou quase inexistentes. A formação de uma opinião pública em prol da preservação contribuiu também para essa ampliação e, assim, para a patrimonialização das derradeiras "sobras" de nossa modernização urbana incompleta. A preservação mais intensiva das áreas localizadas na periferia dos núcleos dinâmicos centrais das três cidades surgiu - inicialmente em Salvador e, depois, sucessivamente, no Rio de Janeiro e em São Paulo - como iniciativa vinculada ao aproveitamento econômico do patrimônio construído. 
Os projetos implementados durante os anos 1990 nas três cidades estudadas foram, assim, marcados por histórias urbanas e de preservação específicas, se bem que pontuadas por aspectos comuns. Todas as suas áreas centrais sofreram, a partir do século XIX, sucessivos processos de deslocamento de funções que configuraram espaços diferenciados, tanto em termos de dinâmica quanto de utilização. Contudo, as três cidades chegaram à metade do século XX com uma estrutura ainda fortemente polarizada em uma única centralidade, que só se tornou inadequada e crítica com o intenso crescimento urbano impulsionado pela aceleração da industrialização nos anos 1950. A fragmentação terciária provocada por esse crescimento formou novas centralidades nas três capitais, mas esse processo teve intensidades e durações distintas e promoveu impactos diversos nas áreas centrais de cada uma delas. A natureza e a abrangência desses impactos decorreram de especificidades locais relacionadas: (a) ao grau de polaridade econômica, regional e nacional de cada cidade; (b) a decisões ou omissões de planejamento, em nível local e regional; (c) ao grau de acessibilidade e de infraestrutura instalada de cada área central; (d) ao volume de investimentos feitos nesse sentido, após a aceleração do processo de deslocamento de funções; (e) aos investimentos em infraestrutura urbana realizados em outras áreas da cidade; (f) à localização dos vetores mais dinâmicos de investimentos imobiliários; e, por fim, ainda que secundariamente, (g) ao grau de constrangimento interposto pelas legislações urbanísticas e de proteção à renovação desses setores centrais.

Em Salvador, o processo de esvaziamento e de perda de hegemonia do centro antigo foi o mais intenso e o mais induzido pelo poder público, tanto por meio dos investimentos realizados em outras áreas da cidade quanto mediante as diretrizes de planejamento que foram implementadas. Decidiu-se construir e incentivar o surgimento de novas centralidades com o objetivo de desafogar o centro antigo e preservá-lo para o turismo, e, nesse contexto, desenvolveram-se ações de revitalização a partir dos anos 1970. Salvador foi também, entre as três cidades, a que menos contou com investimentos em infraestrutura urbana, acessibilidade e mobilidade no centro antigo depois que o processo de deslocamento de funções centrais foi deflagrado. A despeito do crescimento notável da região metropolitana de Salvador nos anos 1970 e 80, a dinâmica industrial não gerou desenvolvimento econômico e mercado suficientes para manter dois centros 
urbanos com características equivalentes de polaridade. O turismo, por sua vez, tampouco se desenvolveu na intensidade esperada, de modo a redinamizar o centro antigo. O efeito do deslocamento de funções e da concentração de investimentos nas novas áreas de expansão foi esvaziar o centro antigo e dinamizar o novo centro do Vale do Camarajipe, completando-se, no final dos anos 1990, o deslocamento da hegemonia de um para o outro, apesar de, em termos simbólicos e de urbanidade, o "centro" ser ainda associado ao centro antigo. Até meados da última década do século XX, as duas centralidades ainda dividiam primazia na estrutura urbana - uma como centro de comércio popular, e a outra como centro de comércio dos segmentos de maior renda. No começo dos anos 2000, a primazia do centro já era incontestável, o que criou grandes dificuldades para a atração de investimentos no centro antigo - que assim adquiria, cada dia mais, características de um subcentro de atendimento a camadas populares.

A morfologia da cidade antiga e as áreas preservadas na capital baiana jamais criaram constrangimentos intransponíveis à modernização e à expansão do centro. Quando as primeiras pressões nesse sentido se instalaram nos anos 1960, o bairro do Comércio, na Cidade Baixa, - que abrigava a área central de negócios da cidade - foi renovado em grande parte. Nesta área, o gabarito das edificações novas foi fixado em 45 m, o que permitiu a renovação do setor, aliviou as pressões e garantiu a preservação dos conjuntos históricos localizados na cidade alta. Em Salvador, como em São Paulo, a transferência de funções centrais para novas áreas de expansão resultou muito mais de uma política de concentração de investimentos nesses setores e do favorecimento do capital imobiliário do que de qualquer outro fator.

Em São Paulo, o esvaziamento do centro antigo foi intenso nos anos 1970, e sua posterior apropriação popular também foi alta. Houve, entretanto, nos anos 1970 e 80, investimento pesado em acessibilidade e, apesar do êxodo de funções para novas centralidades, o centro antigo ainda mantinha, nos anos 1990, algumas características de centralidade principal. São Paulo passou, contudo, por um processo de deslocamento e fragmentação do centro, orientado pelo mercado imobiliário, sem que o poder público fizesse qualquer coisa para impedi-lo. Mesmo mantendo-se como o principal polo urbano e econômico do país ao longo de todo o século XX, a cidade não abrigou dinâmica econômica suficiente 
para manter, em pé de igualdade, três centros com características semelhantes. Assim, o surgimento de cada nova centralidade significou o esvaziamento e a decadência relativa da anterior. No início dos anos 1990, São Paulo apresentava um sistema de centros desequilibrado e sem primazia clara. Foi, inicialmente, contra esse desequilíbrio e no sentido de promover um movimento de retorno de funções para o centro antigo que as ações de requalificação daquela década se estruturaram.

No Rio de Janeiro, a hegemonia do centro antigo na estrutura urbana foi mais preservada, com o setor mantendo-se como um polo de atividades forte no plano municipal, metropolitano e nacional. A cidade possuía, nos anos 1990, o sistema de centralidades mais equilibrado entre os casos examinados, ao ter inviabilizado, com os investimentos feitos no centro antigo a partir dos anos 1980, o projeto de criação de um novo centro metropolitano na Barra da Tijuca. Esse equilíbrio e essa hegemonia, contudo, eram precários, pois dependiam do redirecionamento de investimentos imobiliários para o centro da cidade e do sucesso das iniciativas de inclusão das camadas populares no mercado formal de habitação. De todo modo, no Rio de Janeiro, as intervenções realizadas durante os anos 1990 encontraram um cenário urbano mais favorável do que os de Salvador e São Paulo, que foi gerado também pela qualidade da política de preservação desenvolvida nos anos 1980 e pelo consenso construído a respeito da preservação do patrimônio do centro.

As iniciativas mais amplas de conservação e valorização do patrimônio edificado, que precederam as intervenções dos anos 1990, tiveram início em momentos distintos dos processos recentes de reestruturação urbana e formação de centralidades, em cada uma das três cidades focalizadas. Em Salvador, ocorreram no início desse processo e estiveram integradas ao novo papel de polo turístico, atribuído ao centro antigo pelo planejamento local e estadual. No Rio de Janeiro e em São Paulo, no final. No caso do Rio, essas iniciativas foram voltadas para a reanimação de funções e constituíram uma reação à herança de estagnação e esvaziamento legada por uma visão superdilatada do potencial de expansão do núcleo mais dinâmico do centro. No de São Paulo, objetivaram o retorno e a manutenção de funções importantes no centro antigo, após a fragmentação dessa centralidade. 
Assim, não foi por acaso que, em Salvador, as intervenções de preservação do patrimônio do centro histórico, a partir dos anos 1960, tiveram sempre o objetivo de renovar usos e de re-funcionalizar o setor para o turismo. No Rio de Janeiro e em São Paulo, por sua vez, o objetivo foi reforçar a centralidade. Influenciadas pela história local e pelas características do parque patrimonial constituído em cada cidade, as ações executadas nessas áreas centrais nunca estiveram, entretanto, inseridas em planos globais das respectivas cidades. Constituíram ações localizadas e, de certa forma, "cegas" com relação à totalidade urbana, influenciadas, em grande parte, por uma mentalidade preservacionista que se expandiu nos meios técnicos e em certos setores da sociedade a partir dos anos 1970.

A existência de solo mais fértil ou menos fértil para o desenvolvimento dos projetos de requalificação e valorização iniciados ou ampliados nos anos 1990, nas cidades estudadas, relacionou-se, grandemente, à intensidade dos processos de deslocamento de funções centrais e de esvaziamento populacional ocorridos em cada uma, às consequências que esses processos trouxeram em termos de reestruturação dos espaços centrais e à capacidade que cada projeto teve de lidar com esses fatores. A posição e a função da centralidade na estrutura urbana, bem como a quantidade e qualidade dos investimentos realizados em acessibilidade e infraestrutura ao longo do tempo, desempenharam papéis importantes nas possibilidades de sucesso dos programas iniciados. O Rio de Janeiro, por ter logrado manter mais intacta a dinâmica e a importância de sua área central de negócios, e por ter dado continuidade à política de preservação iniciada nos anos 1980, foi a única das cidades estudadas que conseguiu promover um processo de preservação mais consolidado. Esse sucesso deveu-se à qualidade das estratégias desenvolvidas, mas também ao contexto histórico e urbano em que se implantaram.

No início dos anos 1990, cada cidade já possuía, então, em maior ou menor grau, uma "experiência" de preservação do patrimônio das respectivas áreas centrais, que influenciou as novas intervenções. Cada cidade contava também com uma história de esvaziamento e perda de funções que determinou, em muito, as chances de sucesso dessas novas iniciativas. 


\section{Características comuns e especificidades}

Salvador foi a única das três cidades onde não se não relacionou a intervenção na área central à problemática intraurbana de esvaziamento e deslocamento de funções. Foram focalizados, sem visão mais abrangente, apenas setores do centro histórico há muito depreciados e postos à margem da dinâmica do núcleo central, implantando-se ações que substituíram o perfil residencial dessas áreas e romperam radicalmente com as iniciativas anteriores de desenvolvimento social e melhoria das condições de vida da população moradora. O fracasso dessas iniciativas passadas foi, inclusive, atribuído ao fato de terem buscado manter a população residente na área. A nova intervenção no Pelourinho, iniciada em 1992, teve forte intenção de promoção governamental, integrando-se, em seguida, aos planos estaduais de desenvolvimento do turismo. Não se relacionou, portanto, a questões da cidade, mas a estratégias de desenvolvimento econômico e de comunicação do governo estadual.

No Rio de Janeiro e em São Paulo, o papel do centro antigo nas estruturas policêntricas dessas cidades foi sempre considerado um dado essencial. As intervenções dos anos 1990 destinaram-se a reforçar esse papel e a tornar esses centros antigos atraentes para novos investimentos e atividades de alcance metropolitano e municipal. Numa e noutra cidade, a questão do turismo esteve presente, mas não como eixo principal. O estímulo ao desenvolvimento de atividades culturais e de lazer constituiu um traço importante, mas inseriu-se também na problemática de reforço dessas áreas. Assim, as intervenções no Rio e em São Paulo destinaram-se a fortalecer os centros antigos como áreas estratégicas para o desenvolvimento da economia urbana, por meio do reforço de suas potencialidades e da atração de atividades contemporâneas vinculadas ao chamado "terciário avançado".

Na segunda metade na década de 1990, os "vazios" deixados pelas perdas demográficas e funcionais surgiram, simultaneamente, como um problema a ser enfrentado nos processos de requalificação e uma oportunidade para o desenvolvimento de novos projetos nos bairros centrais do Rio de Janeiro e São Paulo. O reaproveitamento desses espaços acabou tomando, em São Paulo, o caminho do desenvolvimento do uso habitacional de caráter popular e, no Rio, o da implantação 
de projetos multifuncionais baseados no incentivo à produção imobiliária. No final da década, a questão da utilização desses novos "vazios urbanos construídos" e da necessidade de redirecionar o crescimento da cidade para as áreas centrais urbanizadas já suplantava o problema do deslocamento e da fragmentação de funções centrais como móvel das intervenções nessas duas metrópoles. Em Salvador essa questão surgiu mais tardiamente, influenciada pelos projetos de aproveitamento habitacional em andamento no Rio de Janeiro e em São Paulo e pelos programas nacionais de preservação que foram implantados no final da década.

O desenvolvimento do uso habitacional como alternativa para a dinamização e o aproveitamento de setores centrais ganhou peso, em cada cidade, em decorrência de fatores distintos. Em Salvador, como resultado da não sustentabilidade da intervenção comercial e turística realizada no centro histórico; da busca de recursos e alternativas para dar continuidade ao processo de recuperação; e do aprofundamento do esvaziamento da área do Comércio, com a transferência maciça do setor financeiro para o novo centro do Vale do Camarajipe, na segunda metade dos anos 1990. No Rio de Janeiro, como estratégia para sustentar o processo de requalificação e valorização do núcleo dinâmico do centro e, em São Paulo, para atender às reivindicações dos movimentos sociais por moradia que invadiram imóveis no centro antigo. Nos três casos, o movimento em direção ao desenvolvimento do uso habitacional foi propiciado também pelas mudanças implementadas na política nacional de habitação, o que permitiu a implantação de linhas de financiamento destinadas à melhoria do habitat. O movimento de reconquista habitacional de áreas centrais encontrou ainda justificativa na necessidade de intensificação do uso de áreas bem dotadas de infraestrutura e equipamentos, diante do arrefecimento do crescimento demográfico nas grandes metrópoles e do fenômeno de esvaziamento de áreas de urbanização mais antiga e consolidada.

O foco das intervenções no núcleo mais dinâmico do centro e sua extensão posterior aos bairros periféricos é um traço marcante do processo do Rio de Janeiro, surgido da necessidade de se consolidar os investimentos realizados no núcleo principal. O vínculo com o turismo teve, em Salvador, grande influência na concentração das intervenções nos sítios históricos do centro antigo, bem como nos logradouros e corredores viários mais importantes que thes dão acesso. 
A maioria das intervenções nessa cidade localizou-se, assim, ao longo dos "caminhos do turismo", não focalizando nem a área comercialmente mais dinâmica do centro, nem a área central como um todo.

Em São Paulo, intervenções e projetos se concentraram de modo mais ou menos equilibrado no núcleo mais dinâmico do centro e em setores específicos da área central. A depender, entretanto, de sua vinculação ao projeto de dinamização econômica e valorização imobiliária ou ao de reanimação do uso habitacional, focalizaram, preferencialmente, setores distintos. No primeiro caso, o foco foi posto nos distritos que compõem o núcleo funcionalmente mais importante do centro e em determinados sítios históricos da área central, como o bairro da Luz. No segundo, em qualquer setor do centro ou dos bairros centrais que abrigasse edifícios e terrenos vazios ou subutilizados. Neste caso, a localização foi esparsa, descontínua e bastante influenciada por oportunidades de ocupação e aquisição. Só depois do fim da década de 1990 é que as intervenções de desenvolvimento do uso habitacional se vincularam a perímetros delimitados em áreas de concentração de habitações subnormais. Em Salvador, assim como no Rio, a localização dos projetos habitacionais foi comandada por oportunidades de aquisição e ocupação relacionadas à existência de ruínas, imóveis e terrenos vazios. Nessas cidades, a localização desses projetos também foi dispersa e descontínua.

Em termos gerais, contudo, pode-se afirmar que, no Rio e em São Paulo, predominou a tendência de se concentrar as intervenções nos setores de maior dinâmica das áreas centrais. Apenas no final da década de 1990 surgiu a tendência de focalizar ou projetar intervenções para as áreas periféricas esvaziadas que apoiam ou exercem influência na dinâmica dos núcleos principais dessas cidades. Os projetos públicos, tanto numa cidade quanto na outra, passaram a considerar todas as respectivas áreas centrais somente no começo dos anos 2000.

Quanto ao tipo e à natureza das intervenções, verifica-se uma notável semelhança entre as três cidades, embora, em cada uma, a execução de determinado tipo seja mais ou menos intensa, e mais ou menos bem sucedida. Invariavelmente, todas elas realizaram intervenções de natureza física e de controle do uso do solo e dos espaços públicos de modo articulado. Em todas, as intervenções se estruturaram, inicialmente, com vistas à dinamização econômica e à valorização imobiliária das áreas centrais. Ao longo da década, entretanto, a depender da 
maior ou menor viabilidade demonstrada por essas estratégias e da intensidade dos seus resultados, foram surgindo outras voltadas para o desenvolvimento da função residencial.

As intervenções físicas voltaram-se, principalmente, para a realização de "melhorias" na aparência e no funcionamento dos espaços e logradouros públicos, para a reciclagem de imóveis, a recuperação de fachadas, a valorização de objetos arquitetônicos destacados, a inserção de objetos artísticos no espaço público e valorização dos existentes. Incluíram ainda o deslocamento de terminais de transportes públicos, a provisão de estacionamentos privados e a instalação de mobiliário urbano. Em suma, essas intervenções buscaram criar ambientes urbanos agradáveis, ordenados e atraentes para determinados tipos de atividades. O Rio de Janeiro foi a cidade onde as intervenções de requalificação de espaços públicos mais se desenvolveram e, em seu conjunto, atingiram uma área maior e mais contínua no centro antigo. Em São Paulo e em Salvador - em que pese a intervenção maciça no Pelourinho -, as intervenções de requalificação urbana foram mais pontuais, privilegiando vias e logradouros públicos de maior simbolismo e visibilidade.

As intervenções de gestão e controle dos espaços públicos caracterizaram-se pela eliminação ou pelo ordenamento do comércio informal, controle da presença de moradores de rua, melhoria da segurança pública ou implantação de segurança privada; e ainda foram marcadas pelo ordenamento da exibição de publicidade e realização de eventos em praças e ruas. Apenas em São Paulo, no final da década de 1990, as intervenções de controle da presença da pobreza e de suas formas de sobrevivência na área central foram acompanhadas de projetos de assistência e inserção social, capacitação e geração de trabalho e renda.

As intervenções de reciclagem de imóveis para uso habitacional foram muito poucas em todas as cidades estudadas, não apenas porque esses projetos surgiram tardiamente, mas, principalmente, em decorrência de entraves burocráticos, fundiários, documentais, urbanísticos, tecnológicos e vinculados às limitações das linhas de financiamento existentes. A execução limitada desse tipo de intervenção decorreu ainda da falta de interesse do setor imobiliário e da construção civil pelas localizações centrais e também foi resultado da dificuldade de acesso, por parte dos segmentos de menor renda, ao mercado formal de habitação e aos financiamentos disponíveis. As linhas de financiamento para 
a produção habitacional surgiram no final dos anos 1990, mas seu uso foi muito restrito, devido à sua inadequação à reabilitação de imóveis históricos, conforme visto no Capítulo 5. Em Salvador e no Rio de Janeiro, as intervenções voltadas para o uso habitacional de interesse social foram incorporadas aos projetos de dinamização econômica e terciária, com um caráter complementar. Em São Paulo, os projetos de requalificação e reanimação econômica e os de uso habitacional se desenvolveram em campos opostos e antagônicos. Apenas no final daquela década foram realizados esforços no sentido de torná-los complementares.

Nenhum desses conjuntos de intervenções nas áreas centrais das cidades em foco obedeceu a planos globais para esses setores. Em Salvador, a intervenção do Pelourinho constituiu um projeto bastante circunscrito territorialmente e as demais intervenções pontuais de requalificação de vias e logradouros da área central tampouco se articularam a um plano de maior alcance. Contudo, foram guiadas por uma lógica comum, a de valorizar o patrimônio do setor e desenvolver o turismo. Assim, se pode afirmar que se articularam ao plano estratégico de turismo do governo estadual - instância que financiou e se responsabilizou pela maioria das intervenções. No Rio de Janeiro tampouco houve plano global. Os atores públicos e privados se articularam espontaneamente, em decorrência da política desenvolvida pelo município desde os anos 1980 e do já mencionado consenso firmado sobre os rumos da preservação do patrimônio do centro. Esse consenso tornou as ações públicas e privadas complementares e thes imprimiu uma lógica de reforço e valorização da centralidade. (MAGALHÃES, 2001)

São Paulo também executou intervenções pontuais, mas foi a cidade que mais investiu na elaboração de planos para o núcleo do centro e para a área central. Embora praticamente não tenham sido executados no período em foco, esses planos guiaram as intervenções que lograram se concretizar. Apesar do baixo índice de execução, decorrente, em grande parte, de um excesso de otimismo com relação à participação da iniciativa privada nos projetos propostos, esses planos contribuíram para desenvolver e consolidar um pensamento sobre a área central que colocou São Paulo à frente das outras cidades em termos de propostas e possibilidade de viabilização dos seus projetos.

O papel do poder público como formulador, coordenador, financiador, gestor ou executor dos projetos e intervenções nas áreas centrais das cidades estudadas 
foi o tempo todo fundamental. Apenas em São Paulo a formulação, coordenação e gestão dos processos foram compartilhadas com a iniciativa privada e com a sociedade, que, entretanto, não tiveram participação igual no que toca à execução. Na maior parte do período enfocado, o poder público foi posto numa posição de executor dos planos de uma associação de empresários e proprietários urbanos, verificando-se a alteração dessa característica apenas no final da década, quando a municipalidade reassumiu o papel de ente formulador e coordenador do processo. No Rio de Janeiro e em Salvador, ao contrário, a liderança do poder público - municipal, no primeiro caso, e estadual no segundo -, foi clara e inquestionável em todos os momentos. A diferença é que, no Rio, a iniciativa privada contribuiu executando algumas intervenções e, em Salvador, todo o processo ficou a cargo do poder público. De um modo geral, portanto, o principal ator dos processos de "recuperação", "requalificação", "repovoamento" ou "reabilitação" estudados foi mesmo o Estado. Segmentos empresariais, comerciantes, corporações, agências financeiras nacionais e internacionais e sociedade civil organizada se envolveram, mas com intensidades e papéis bem diferentes em cada caso.

A participação da sociedade civil organizada variou muito em cada caso. Em Salvador, a população habitante das áreas que sofreram intervenção não participou do processo, tendo sido, simplesmente, indenizada e empurrada para fora. No Rio de Janeiro, as associações de bairro e de comerciantes, tão atuantes nos anos 1980, ficaram silenciosas. ${ }^{2}$ O setor empresarial carioca, o principal beneficiado, não teve necessidade de se manifestar. Em São Paulo, contudo, a participação da sociedade foi uma das alavancas dos processos de requalificação de espaços públicos e de reabilitação de imóveis para uso habitacional, tendo funcionado como motor da continuidade dessas ações na área central. Os movimentos sociais por moradia e suas assessorias técnicas disputaram espaço com as associações empresariais, contabilizando importantes conquistas no que toca à concretização de operações, à formulação de uma política habitacional para a área central paulistana e à inclusão de ações de interesse social nos programas formulados para o centro.

Os modelos de intervenção construídos, em cada cidade, a partir do somatório das ações realizadas, dos projetos e planos eventualmente propostos, abordaram e buscaram atrair de modo distinto a participação do setor privado,
1 A Associação Viva o Centro. Ver mais a respeito no capítulo 4

2 Apenas uma associação, a ACCRA, ligada aos comerciantes da Rua do Lavradio e arredores, na Lapa, influenciou e participou do projeto de requalificação por meio do encaminhamento de reivindicações à prefeitura e da mobilização da mídia em torno dos problemas dessa via. Pesou no atendimento dessas reivindicações o fato de a Rua do Lavradio vir sendo utilizada periodicamente para a realização de feiras de antiguidades que atraem moradores da Zona Sul, e de estar se transformando, à época, em um ponto de entretenimento dessas camadas. 
mas tiveram, na prática, como traço comum, a predominância de investimentos públicos de modo direto ou mediante incentivos fiscais. Em Salvador, não foram utilizados incentivos fiscais ou instrumentos urbanísticos para a atração de investimentos privados, mobilizando-se apenas, por curto tempo, mecanismos especiais de incentivo à instalação de atividades no setor recuperado. Já no Rio de Janeiro e em São Paulo, o uso de incentivos foi igualmente intenso, mas com resultados muito diversos. No Rio, apoiados no sistema de preservação e apoio técnico montado pela prefeitura nos anos 1980, os incentivos fiscais municipais desempenharam papel fundamental no processo de requalificação do centro, animando o investimento privado nos setores protegidos próximos à área central de negócios. Além desses, os incentivos fiscais do Governo Federal desempenharam igualmente um papel importante na recuperação de edifícios históricos para uso institucional ou cultural. Nessa cidade, o bom funcionamento dos incentivos fiscais como instrumentos de preservação se relacionou ao valor alto do imposto territorial e urbano no centro, à continuidade da política municipal de preservação e à incorporação desses incentivos às dinâmicas de uso comercial e cultural existentes, às quais deram novo impulso. Flexibilizações de legislação e vantagens urbanísticas não foram utilizadas no Rio de Janeiro durante o período estudado.

A flexibilização do aparato legal urbanístico foi, em contrapartida, muito intensa em São Paulo, bem como a relacionada à mobilização de incentivos fiscais. Entretanto, os resultados propiciados por esses instrumentos foram bem menores do que no Rio de Janeiro. Em São Paulo, a iniciativa privada e os proprietários urbanos, de um modo geral, não se interessaram por esses dispositivos, apesar das grandes vantagens oferecidas. Assim, não foram eficazes como instrumentos de preservação e de incentivo à produção imobiliária. Diferentemente do Rio de Janeiro, o valor dos imóveis localizados no centro de São Paulo não é tão alto, e os investimentos do setor privado estiveram mais concentrados fora da área central.

Os instrumentos de política urbana consagrados pelo Estatuto da Cidade no ano 2000 também tiveram presença muito diferenciada em cada modelo local. Em Salvador, não foram mobilizados, fazendo-se apenas um uso mais sistemático do instituto da desapropriação. Em São Paulo, alguns desses instrumentos, como as operações urbanas consorciadas e interligadas, foram ampla e precocemente 
utilizados, mas sem resultados na mudança do quadro da área central. Nessa cidade e no Rio de Janeiro, os dispositivos voltados para o controle e a inibição da especulação imobiliária surgiram apenas em propostas da década de 2000. A estruturação de mecanismos específicos de gestão urbana não chegou a ser uma característica das intervenções nas cidades estudadas. Apenas São Paulo, com a implantação da Comissão ProCentro, apresentou algum avanço nesse sentido.

Embora o uso de recursos públicos tenha predominado em todos os casos estudados, no que toca à estruturação e utilização de instrumentos financeiros, fiscais, legais e urbanísticos, as intervenções não adotaram um formato único e apresentaram variações ligadas às circunstâncias políticas e às dinâmicas locais. Conservaram, entretanto, um traço comum: os incentivos criados se dirigiram, basicamente, a empresas e a proprietários urbanos. Estes, nas diversas combinações resultantes da parceria entre setor público e setor privado, foram os grandes beneficiados e as forças mais incentivadas.

Em geral, todos os processos locais relacionaram-se de modo incipiente com os programas nacionais de preservação, mas, com relação ao PRONAC, seus benefícios fiscais desempenharam papel essencial no Rio de Janeiro e em São Paulo. Nessas cidades, grandes edifícios foram restaurados e funcionaram como importantes equipamentos culturais, graças a esse programa. Somente no final dos anos 1990, o Programa de Revitalização de Sítios Históricos, da Caixa Econômica Federal, e o Programa Monumenta produziram algum impacto nas intervenções locais que estavam em andamento e nos seus planos futuros. O primeiro, no que toca à animação dos projetos relacionados ao desenvolvimento do uso habitacional, e o segundo, na complementação de recursos para ações já em desenvolvimento.

As intervenções em Salvador, no Rio de Janeiro e em São Paulo relacionaram-se de modo distinto com questões urbanas emergentes e com diretrizes estabelecidas para o desenvolvimento regional. Em Salvador, como visto, relacionaram-se ao plano estadual estratégico de desenvolvimento do turismo, no âmbito do fortalecimento e da renovação do "produto turístico Salvador". No Rio de Janeiro, a requalificação do centro sempre foi pensada como uma ação para a cidade, relacionada à sua dinâmica e uso cotidiano. A vinculação das intervenções 
na área central com questões regionais só surgiu em meados da década de 1990, quando alguns projetos, como o Teleporto e o Porto do Rio, buscaram sinergia com programas de dinamização da região, como polo de transporte marítimo, comércio internacional e produção de petróleo. Em São Paulo, por outro lado, entraram na pauta dos projetos para o centro todas as questões urbanas emergentes. Em contrapartida, sua vinculação a questões regionais foi pouco desenvolvida, exceto quanto ao reforço do centro antigo como polo cultural e de negócios de alcance regional, nacional e internacional. Os problemas em torno da questão do uso habitacional de interesse social foram, sem dúvida, as que mais mobilizaram ações contra e a favor, no processo paulistano. Pode-se afirmar, portanto, que o grau de vinculação das intervenções estudadas a problemas locais e regionais foi distinto, assim como foram distintas as questões centrais que os dominaram ao longo da década. Em Salvador, o turismo; em São Paulo, a habitação e os negócios; e no Rio de Janeiro, a cultura e o lazer.

A despeito de suas tendências específicas - ligadas às características, fracassos e conquistas de cada processo local -, verifica-se que os modelos de intervenção construídos nas cidades examinadas buscaram se aproximar, ainda que de modo incompleto e com contornos específicos, das intervenções urbanas realizadas em países desenvolvidos, cujo modelo foi transportado para cá na década em exame. Esse modelo, que tem a cooperação entre os setores público e privado como pilar central do aproveitamento econômico e imobiliário de áreas deterioradas e esvaziadas, foi tentado, de algum modo, em todas as cidades estudadas. Contudo, em contextos de depreciação econômica mais forte, seu poder indutor de transformações revelou-se muito limitado e pouco capaz de promover alterações no quadro urbano. Em compensação, nas áreas em que foram iniciadas ações vinculadas à dinâmica de uso e à demanda habitacional existente, embora incipientes e pouco desenvolvidas, mostraram um grande potencial. Na medida em que o poder de regeneração do modelo importado foi se mostrando fraco, em contato com nossa realidade política, econômica e social, surgiu a tendência de conjugá-lo a ações de produção habitacional para rendas mais baixas. Essa tendência foi se configurando por meio da montagem de um modelo de intervenção híbrido ou do estabelecimento de territórios ou setores específicos para o desenvolvimento de intervenções de uso habitacional. 
Em ambos os casos, as ações vinculadas à dinamização de atividades econômicas e imobiliárias tenderam a se concentrar, preferencialmente, nos núcleos mais dinâmicos dos centros e nas áreas com maior potencial de renovação. Já as relacionadas à produção habitacional tenderam a se localizar nos interstícios dessas áreas, nos bairros periféricos aos núcleos centrais e nos setores de maior concentração de imóveis de valor histórico. ${ }^{3}$

O desafio colocado a esse modelo era o de ser capaz de controlar, eficazmente, os efeitos da valorização imobiliária que fatalmente se desencadearia à medida que os projetos de requalificação avançassem, permitindo que os segmentos de menor renda interessados em morar próximos ao centro pudessem ser beneficiados. O uso dos instrumentos de democratização do acesso ao solo urbano instituídos pelo Estatuto da Cidade tornou-se, assim, importante. A manutenção de um delicado equilíbrio entre valorização e inclusão social, ou entre livre mercado e proteção estatal, surgiu então como a possibilidade mais viável de criação de um modelo de reabilitação urbana adequado às condições urbanas brasileiras.

\section{Resultados projetados e obtidos}

Em comparação com as metas projetadas, verifica-se que os resultados das intervenções em Salvador e em São Paulo ficaram bastante aquém do esperado. No Rio de Janeiro, obtiveram sucesso no núcleo dinâmico do centro e em suas imediações, mas os reflexos nos bairros periféricos foram pequenos. Esses resultados estão relacionados, naturalmente, aos vários fatores "internos" e "externos" que, com intensidades distintas, interagiram com as intervenções realizadas. Os internos se relacionam à concepção das intervenções e aos modelos adotados, a questões políticas locais e à dinâmica econômica e de uso de cada área central. Já os fatores "externos" vincularam-se à economia urbana e regional, à dinâmica de ocupação e expansão da cidade, ao peso da centralidade na estrutura urbana e, não menos importante, ao valor de mercado atribuído ao patrimônio pela população local. Em suma, os resultados das intervenções realizadas decorreram de múltiplos fatores, que ultrapassaram, em muito, a questão da preservação ou da conservação do patrimônio. 
Em Salvador, o fracasso da ocupação turística e comercial do Pelourinho está relacionado a vários desses fatores, mas especialmente ao fato de a intervenção ter sido utilizada, prioritariamente, como instrumento de marketing pelo governo estadual, e de se insistir em sustentá-la a partir do turismo, sem nenhum vínculo com a dinâmica de uso e ocupação do entorno. Trata-se, em suma, de um problema de inadequação do modelo ao meio e à dinâmica local, o que, somado ao equívoco do modo de gestão adotado, resultou em sérias dificuldades para se promover uma preservação sustentada do setor. Em outras palavras, o modelo de intervenção e de gestão construído no Pelourinho - excessivamente centrado no governo estadual e em uma concepção equivocada de empreendimento turístico e comercial - não foi capaz de cumprir a finalidade de conservar o patrimônio edificado, de deflagrar uma dinâmica de ocupação "saudável" no entorno e de exonerar o poder público de investimentos constantes na preservação do conjunto. Fatores "externos", ligados ao peso e ao papel do centro antigo na atual estrutura de Salvador, aos hábitos de compra e de lazer da classe média e às dificuldades de desenvolvimento do turismo no estado também contribuíram para o malogro dessa intervenção.

O fato de o centro antigo de Salvador abrigar cada vez menos funções direcionais e tipicamente centrais, caracterizando-se no âmbito do sistema de centralidades de Salvador como um centro de comércio e serviços de caráter popular, dificulta a atração de atividades com outro perfil, bem como o interesse do seu público correspondente. Com a conclusão do processo de formação de novas centralidades, iniciado nos anos 1960, surgiram na cidade vários polos de comércio, animação e lazer que concorrem fortemente com o novo Pelourinho. Ao lado disso, o número de turistas não foi suficiente para sustentar o empreendimento nos moldes em que foi desenhado.

Embora as iniciativas relacionadas ao desenvolvimento do uso habitacional não tenham saído completamente do papel, seus horizontes, como alternativa para a recuperação sustentada de setores deteriorados do centro histórico de Salvador, pareciam claros no começo dos anos 2000. Pesquisas da época mostravam que havia uma grande demanda de unidades habitacionais para faixas de renda média e baixa na área central, o que a dinâmica residencial e comercial da zona confirmava. Entretanto, essa alternativa foi prejudicada pela ausência 
de articulação dessas ações pontuais a um projeto global, que incluísse a solução dos entraves urbanísticos, ${ }^{4}$ de acessibilidade e de mobilidade urbana que dificultavam o uso residencial na área. Ao lado disso, a falta de propostas no sentido da criação de mecanismos de controle da valorização do solo, caso o uso habitacional se desenvolvesse, criaria, certamente, obstáculos para o acesso dos segmentos de renda que demandavam a área central. ${ }^{5}$ Embora a região não fosse ainda cobiçada pelos segmentos de alta renda, os investimentos em requalificação de vias e logradouros, na valorização de sítios históricos, bem como os que estavam projetados para a Cidade Baixa, reforçaram o processo de gentrificação que já havia começado a se instalar nas bordas do centro histórico voltadas para a Baía de Todos os Santos. Desse processo, davam testemunhos eloquentes o comércio e os serviços ultrassofisticados instalados na Avenida Contorno e a alta no preço dos imóveis da Rua Direita de Santo Antônio, em decorrência de sua ocupação por estrangeiros.

Os projetos de dinamização econômica e intensificação do uso da área central de Salvador enfrentaram, ainda, uma carência que não se verificava nas demais cidades estudadas: a falta de dados organizados que permitissem monitorar a dinâmica comercial, residencial e de serviços do setor, bem como sua relação com as dinâmicas de outras áreas e centralidades da cidade. Diferentemente de São Paulo, onde a municipalidade era pródiga nesse sentido, em Salvador não existiam, no começo dos anos 2000, informações básicas, por exemplo, sobre arrecadação de IPTU, ISS ou ICMS, organizadas por bairros ou regiões administrativas. Conforme observado no capítulo que focaliza essa cidade, as políticas de preservação e valorização do patrimônio urbano foram elaboradas e executadas às cegas, sem visão geral dos processos e dinâmicas em curso na cidade. Esse, sem dúvida, foi um outro fator que prejudicou sua efetividade.

No centro da cidade de São Paulo, as dificuldades de consolidação e ampliação dos projetos de requalificação ambiental, dinamização econômica e valorização imobiliária estiveram relacionadas a uma estratégia excessivamente baseada na atração de investimentos privados de grande monta. Esta opção fez com que ganhassem peso considerável na viabilização das intervenções fatores como o papel atual do centro antigo na estrutura urbana; os vetores de concentração de investimentos imobiliários; a dinâmica econômica da
4 Falta de estruturas de apoio, como comércio de caráter local, áreas de lazer, escolas, postos de saúde e demais equipamentos necessários ao desenvolvimento do uso habitacional.

5 Diferentemente de São Paulo, no projeto de Plano Diretor de Desenvolvimento Urbano e Ambiental de Salvador, iniciado no começo dos anos 2000, não foram propostas Áreas de Especial Interesse Social na área central. 
cidade; e o valor de mercado atribuído à localização central e ao seu patrimônio. A perda de importância do centro antigo de São Paulo como polo de atividades administrativas, direcionais, financeiras, comerciais e de serviços, bem como a adaptação de muitas dessas atividades a um perfil popular, fez com que a área perdesse atratividade como localização preferencial de atividades ligadas aos estratos de renda mais alta, dificultando o redirecionamento de investimentos significativos em reciclagem ou produção imobiliária para o centro. O esforço de requalificação de alguns espaços e a criação de incentivos fiscais e urbanísticos não foram suficientes para atrair esses investimentos, principalmente, em decorrência da ausência de uma ação incisiva que impusesse controles a certos vetores de produção imobiliária que tornavam desinteressantes as vantagens oferecidas no centro. Pesaram, ainda, as dificuldades que sucessivas administrações locais tiveram para equacionar, minimamente, a questão do comércio informal no centro, que, literalmente, ocupava várias de suas vias e praças.

Assim, mesmo com a implantação de uma política de incentivos fiscais e a forte flexibilização operada na legislação urbanística, o quadro de subutilização do centro paulistano permaneceu praticamente inalterado nos anos 1990. Embora novos equipamentos culturais tenham trazido um público mais endinheirado, seu impacto no quadro geral foi baixo. Em vista disso, tornou-se essencial para a reversão do quadro de esvaziamento e desvalorização um plano global de cidade, além de medidas destinadas a estabelecer uma relação mais equilibrada entre as centralidades existentes e um uso mais racional da infraestrutura implantada. O que se verificou, contudo, na maior parte da década de 1990, foi justamente a convivência dos projetos de requalificação do centro com pesados investimentos públicos e incentivos à produção imobiliária nos setores da cidade de maior interesse para o mercado imobiliário formal.

A reversão de quadros de esvaziamento funcional, populacional e econômico em áreas centrais depende, certamente, de muitos fatores, mas o caso de São Paulo mostra, de modo muito claro, o quanto o surgimento de centralidades não planejadas e, ao mesmo tempo, orientadas por interesses imobiliários, pode dificultar ou até inviabilizar esses processos. Mostra claramente, ainda, que, menos do que ao oferecimento de vantagens urbanísticas e fiscais e à realização de intervençóes de melhoria da ambiência, a reversão desses quadros está vinculada a um olhar 
para além do centro e da própria área central. Um olhar, enfim, que abarque não somente os novos centros, mas também a periferia da cidade. Os investimentos do município e do governo estadual nos anos 1990, contudo, atraíram algumas parcerias para a realização de melhoramentos em logradouros públicos, para a restauração de fachadas e de grandes monumentos, assim como para a instalação de centros culturais.

O projeto de uso habitacional de interesse social na área central de São Paulo também encontrou dificuldades para se tornar uma ação sistemática e ampla. Neste caso, contudo, os problemas não se relacionaram à falta de demanda, mas, como já comentado, a entraves fundiários, documentais e burocráticos; às limitações das linhas de financiamento disponíveis e à falta de políticas de subsídios e de desenvolvimento tecnológico. As perspectivas de sucesso do projeto de intensificação do uso e de requalificação do centro de São Paulo aumentaram, entretanto, na medida em que se buscou explorar as potencialidades da área por meio da reanimação de funções tipicamente centrais, como a vinculada à administração municipal, e através do desenvolvimento do uso habitacional. A articulação dessas ações a um plano global para a área central também foi um fator importante que colocou São Paulo, entre os casos estudados, como a cidade que produziu a proposta mais consistente e com melhores chances de viabilização.

No Rio de Janeiro, o projeto de recuperação do patrimônio para reforço e valorização do centro da cidade ajudou a estancar, no seu núcleo mais dinâmico, processos de esvaziamento funcional e deterioração urbana instalados há longa data, contribuindo para manter a hegemonia dessa centralidade na estrutura urbana. O projeto foi importante ainda para manter e até aumentar o valor de mercado dos imóveis, reanimar atividades culturais, de entretenimento e lazer, renovar a ocupação comercial em certas áreas e reaproximar segmentos sociais de renda mais elevada do centro da cidade. O Rio de Janeiro apresentou, entre as cidades estudadas, o caso mais bem-sucedido de recuperação sustentada do patrimônio, embora este sucesso tenha ficado restrito ao seu núcleo mais dinâmico. A periferia do centro, como já observado, manteve o mesmo perfil esvaziado e deteriorado de 20 anos antes.

Vários fatores influenciaram e permitiram o resultado positivo alcançado, nos anos 1990, pela experiência carioca. Entre estes fatores, destacam-se a preservação 
da importância da antiga centralidade no sistema de centros municipais e metropolitanos; a herança legada pelo trabalho educativo e de grande qualidade técnica realizado pelo Corredor Cultural, nos anos 1980; e a continuidade da política de incentivos fiscais municipais então traçada. Essa política impulsionou investimentos privados, gerando um compromisso maior dos ocupantes, proprietários e comerciantes instalados com o projeto do poder público. Por sua vez, os investimentos públicos diretos, realizados nos anos 1990, ampliaram a área recuperada e reforçaram os predicados que, há muito, asseguram a hegemonia do centro antigo na estrutura urbana e metropolitana, isto é, sua posição geográfica estratégica, sua notável acessibilidade e a manutenção de funções institucionais, culturais, financeiras e administrativas importantes.

O alcance restrito dos efeitos positivos ao núcleo dinâmico do centro vinculou-se às características dessas intervenções, mas também às causas históricas do esvaziamento e da deterioração dos demais bairros que compõem a área central da cidade do Rio de Janeiro. Como visto anteriormente, sobre esses bairros se deram os grandes impactos do crescimento urbano orientado para a periferia, bem como do deslocamento de funções que freou a expansão da área central de negócios. A estagnação da economia carioca e fluminense por longo período favoreceu, por seu turno, esse processo de esvaziamento e tornou mais difícil a dinamização dessas áreas com atividades econômicas próprias de uma área central. Paralelamente, os vazios deixados não puderam ser preenchidos pelos segmentos demandantes de moradia central, pois a estrutura fundiária existente, a especulação imobiliária com terrenos centrais e o modelo tradicional de política habitacional não permitiram esse aproveitamento.

Ao lado desses fatores, por assim dizer, estruturais, a periferia do núcleo dinâmico do centro carioca recebeu, historicamente, consideravelmente menos investimentos públicos do que este núcleo, e os programas traçados nos anos 1990 para atendimento à demanda de moradia popular nessa área não deslancharam. Tampouco decolaram, por falta de investidores, os projetos de dinamização econômica e de incentivo à produção imobiliária propostos para essa periferia do núcleo central. A dificuldade de atrair investimentos privados de peso para essa zona se relacionou à permanência de vetores de investimentos dinâmicos e altamente lucrativos na Zona Oeste da cidade, o que foi reforçado pelos investimentos 
públicos em vias de ligação rápida dessa zona com o centro e com as principais saídas da cidade. Além disso, o aproveitamento, a reabilitação e a reciclagem do patrimônio edificado constituíram ações marginais no universo da produção imobiliária brasileira - tendência de mercado que era então determinada (e ainda é) pela permanência, no seio dos segmentos de maior renda, de uma mentalidade que não valoriza a moradia central.

As perspectivas de consolidação, sustentabilidade e durabilidade do processo de intensificação do uso da área central carioca repousavam, portanto, na possibilidade de reabilitar as áreas deterioradas da periferia do centro; na solução dos entraves que impediam o desenvolvimento satisfatório dos programas habitacionais nessas áreas; na criação de mecanismos financeiros e de controle da especulação imobiliária e de subsídios que permitissem atender adequadamente a demanda habitacional existente. Dependiam também da possibilidade de se reorientar vetores de investimentos econômicos e imobiliários por meio de um amplo planejamento territorial e de uma localização criteriosa de investimentos públicos. Faltava, ainda, uma política de subsídios diversificados e adaptados aos vários tipos de produção habitacional que a área central poderia abrigar, além de linhas específicas de financiamento para a reabilitação de imóveis antigos e um programa de desenvolvimento tecnológico no campo da reforma e da reabilitação. Por fim, faltava a delimitação de Áreas de Especial Interesse Social que possibilitassem o reaproveitamento do patrimônio urbano com inclusão dos que, de fato, demandavam moradia no centro.

Os resultados das intervenções realizadas em Salvador, Rio de Janeiro e São Paulo, nos anos 1990, mostram a importância da adequação do modelo de intervenção à realidade econômica e urbana de cada localidade para que processos de utilização intensiva e de dinamização econômica possam alcançar resultados positivos. Mostram também que são fatores essenciais para o sucesso e a sustentabilidade de projetos de aproveitamento do patrimônio edificado: a manutenção de polaridade simbólica e urbana; o reforço de funções centrais, administrativas e habitacionais; a remoção de entraves fundiários e urbanísticos; e uma boa acessibilidade - ou o investimento nesse sentido. O controle e o redirecionamento de vetores de investimento imobiliário, por meio de mecanismos urbanísticos e de investimentos estratégicos, é também essencial, bem como a capacidade de 
6 Salvador constituiu a exceção, com sérios problemas de acessibilidade, mobilidade e oferta de transportes públicos na área central. Os terminais da Lapa, da Barroquinha, do Aquidabã e da França tangenciam o centro histórico, mas não o irrigam. Com a eliminação do Terminal da Sé, o setor teve ainda o número de linhas que percorrem a cumeada do centro histórico reduzidas. Além disso, devido ao Pelourinho ter sido concebido como um enclave turístico, o sistema de transportes públicos remanescente não o atravessava, o que não permitia estabelecer ligação entre os bairros do centro histórico. conter a especulação imobiliária e de planejar o crescimento urbano. A sustentabilidade desses projetos estará ainda relacionada ao solo histórico sobre o qual se implantem, especialmente no que diz respeito à eficiência e à qualidade das políticas urbanas, de preservação e de aproveitamento patrimonial implantadas em épocas passadas. Desempenham também importantes papéis os investimentos públicos e privados historicamente realizados, o nível de organização social existente e a capacidade política dos atores envolvidos de defenderem seus projetos e negociarem espaço. O desenvolvimento de um projeto de cidade que inclua a área central, que encaminhe soluções para problemas de moradia, trabalho, renda e infraestrutura, e contenha uma avaliação correta das potencialidades econômicas de cada localidade, é também fundamental. Em suma, dinamizar, valorizar e reabilitar, com sucesso e durabilidade, o patrimônio de áreas centrais esvaziadas e deterioradas vincula-se à solução de problemas complexos que dizem respeito não apenas a esse setor, mas a toda a cidade. Em outras palavras, a causa dos problemas dos centros históricos está frequentemente localizada fora deles e muito além dos problemas específicos da conservação patrimonial ou da requalificação de ambientes.

As experiências estudadas mostram que os incentivos fiscais, as flexibilizações de aparato legal, o oferecimento de vantagens urbanísticas, a derrogação de normas de proteção ou sua ampliação, embora possam animar investimentos privados, são impotentes, por si só, para redirecionar vetores consolidados de deslocamento funcional e de investimentos imobiliários. Em suma, são incapazes de reverter processos já instalados, provando-se eficientes apenas na consolidação e reforço de tendências configuradas. Ao mesmo tempo, os estudos realizados apontaram para um fato inquestionável: em todas as cidades estudadas, qualquer que tenha sido a intensidade da situação de esvaziamento funcional ou de perda de polaridade econômica, as áreas centrais eram grandemente demandadas como local de moradia pelos segmentos sociais de baixa renda. Assim, a existência, em todas elas, de grande número de imóveis subutilizados ou vazios, de áreas intensamente ocupadas por um comércio de perfil popular, de farta oferta de transportes públicos ${ }^{6}$ e de empregos, as tornava estratégicas para o encaminhamento de soluçôes para os problemas de moradia desses estratos. Diante do crescimento exponencial da habitação informal e precária nos 
grandes centros urbanos, nota-se que a solução desses problemas é estratégica para toda a cidade. Mas o aproveitamento habitacional das áreas centrais para pessoas de renda mais baixa envolve, sem dúvida, a remoção de barreiras legais e burocráticas, que, se houver vontade política, são mais facilmente removíveis do que as interpostas pelo mercado.

A reanimação e a intensificação do uso habitacional nas áreas centrais surgiram nos anos 1990 como o grande desafio das grandes cidades, especialmente diante da impossibilidade de se ocupar todo o território esvaziado dessas áreas com atividades direcionais, administrativas ou produtivas. Se esse uso terá ou não um maior significado social ou contribuirá, efetivamente, para um desenvolvimento mais equilibrado e democrático dessas cidades é uma questão ainda em aberto que se vincula ao nível de organização dos movimentos sociais, e também à adoção de mecanismos de controle da valorização e da especulação imobiliária, e à ampliação ou não dos processos de gentrificação instalados no interior ou nas bordas das áreas centrais estudadas. Enfim, a questão da relevância urbana e social das intervenções em áreas centrais metropolitanas está vinculada a projetos políticos que consigam conciliar a dinamização econômica e a valorização do patrimônio com ações voltadas à melhoria das condições habitacionais e de vida da população.

\section{Os programas nacionais: rupturas, continuidades e identidades}

Todos os programas nacionais de preservação implementados nos anos 1990 possuem antecedentes ou ações correspondentes nos anos 1970, ou seja, no momento em que se firmou no Brasil uma concepção do patrimônio cultural como recurso econômico. De todos os programas, o Monumenta foi o mais vinculado a essa tradição, constituindo, na realidade, uma atualização dos antigos programas de integração do patrimônio a estratégias de desenvolvimento econômico, agora com alicerces fincados na associação entre setor público e setor privado. O vínculo com experiências realizadas nos anos 1980 também foi constante na maioria dos programas. O Programa Nacional de Apoio à Cultura 
- PRONAC se derivou diretamente da antiga Lei Sarney, de 1986, e o Programa de Revitalização de Sítios históricos - PRSH, da Caixa Econômica, inspirou-se na experiência de reabilitação urbana realizada em Olinda, em 1983.

A atração de investimentos privados e a divisão dos encargos da preservação com a sociedade são questões que já estavam presentes nas discussões e iniciativas das décadas de 1970 e 80 . Nessas décadas, entretanto, esse envolvimento foi concebido como uma consequência natural do investimento realizado pelo poder público. Nos anos 1990, foi abordado como algo a ser construído, incentivado e negociado no início das operações. Com exceção do PRONAC, todos os programas daquela década surgiram após dez anos ou mais de retração de investimentos federais nas áreas da preservação do patrimônio e da habitação social.

Os programas anteriores também encaminhavam diferentes modos de aproveitamento econômico e social do patrimônio urbano. Tal como o Monumenta, o Programa de Cidades Históricas (PCH), nos anos 1970, vinculava, prioritariamente, o uso do patrimônio recuperado ao turismo, à cultura e ao lazer, ao passo que o antigo Programa de Recuperação e Revitalização de Núcleos Históricos, assim como o PRSH, propunha um aproveitamento do patrimônio ligado ao desenvolvimento habitacional e ao cotidiano das populaçóes. Vale ressaltar, inclusive, que esta última abordagem surgiu nos anos 1980 como uma evolução do aproveitamento turístico de áreas históricas, decorrente do fracasso do $\mathrm{PCH}$ em promover uma preservação sustentada e progressiva do patrimônio urbano. Nos anos 1990, se assistiu, como resultado do confronto dos novos programas com a realidade urbana, econômica e social do país, ao crescimento da tendência de se privilegiar ações de maior repercussão social, vinculadas à melhoria do habitat e à vida cotidiana das cidades. Não é, portanto, exagerado afirmar que, no que diz respeito aos programas nacionais, os anos 1990 e 2000 repetiram, de modo acelerado e com algumas especificidades, a trajetória dos programas das décadas anteriores.

A implantação da maioria dos novos programas nacionais ocorreu após a explosão de intervenções de requalificação e revitalização de sítios históricos nas maiores cidades brasileiras, as quais foram implementadas e financiadas por instâncias estaduais ou municipais. A federalização dos programas de preservação decorreu, assim, de uma reação do governo central ao fato de ter perdido 
o papel de protagonista no financiamento de ações nesse campo; da renovação do interesse de agências multilaterais de desenvolvimento, como o BID, pelo financiamento de projetos ancorados no aproveitamento econômico do patrimônio; e das mudanças empreendidas na política nacional de habitação, a partir de 1996.

Os interesses do Governo Federal e das agências de financiamento encontraram solo propício e já trabalhado pelas intervenções locais deflagradas no início da década de 1990, o que permitiu que os programas nacionais funcionassem como elementos impulsionadores e, eventualmente, "saneadores" desses processos, e também como deflagradores de novas ações. A retomada de projetos de preservação por parte de agências multilaterais se relacionou, por sua vez, ao crescimento das solicitações de governos locais e também ao surgimento da reabilitação urbana, na América Latina, como um novo campo para a entrada e desenvolvimento de negócios e serviços. ${ }^{7}$ Além dos programas nas áreas de transporte, saneamento e infraestrutura que financiou no Brasil, e em outros países do continente, ${ }^{8}$ o BID, como mostra o Anexo C, concentrou energias e desenvolveu vários programas de incremento do turismo e de preservação do patrimônio na região, alguns dos quais financiados por fundos fiduciários europeus e de outros países desenvolvidos. Essas operações de preservação e revitalização do patrimônio abriram caminho para a formação de parcerias internacionais e, consequentemente, prepararam também o terreno (físico e institucional) para o desenvolvimento de negócios ligados às áreas de transporte, mobiliário urbano, reabilitação imobiliária e outros serviços que buscavam se expandir de países centrais para as recém-abertas economias de países periféricos. A associação do BID ao governo francês no desenvolvimento de ações de reabilitação no Brasil e em outros países da América Latina ilustra bem essa conjuntura e essa articulação de interesses.

Ao lado disso, as mudanças empreendidas na política nacional de habitação propiciaram o direcionamento de linhas de financiamento da Caixa Econômica Federal para o aproveitamento habitacional do estoque imobiliário existente, o que permitiu que o Brasil reunisse algumas das condições básicas para intervir na reabilitação de sítios históricos, e somasse seus recursos aos dos empréstimos externos obtidos junto a agências multilaterais. A transformação da política habitacional em um conjunto de operações submetidas às regras do mercado também
7 Além desses fatores mais visíveis, a neutralização das reivindicações sociais, decorrente das novas relações impostas pela reestruturação do sistema produtivo e da expansão da ideologia neoliberal, permitiu que governos e agências multilaterais de desenvolvimento desviassem energias para projetos não necessariamente vinculados à solução de tensões sociais, e mais voltados para o desenvolvimento da iniciativa privada.

8 No Brasil, por exemplo, o BID financia programas como o Favela Bairro, no Rio de Janeiro, e outros de saneamento e de implantação de transportes de massa, como o "Baía Azul" e o metrô, em Salvador; o projeto de despoluição da Baía de Guanabara; a ampliação do metrô de Belo Horizonte, entre outros. 
facilitou a montagem de programas de reabilitação do patrimônio edilício. Por meio de novas modalidades de atribuição, como o arrendamento, afastou-se o "fantasma" da inadimplência e conferiu-se rentabilidade e viabilidade financeira aos programas habitacionais. De fato, caso não cumprisse com seus encargos mensais, o novo mutuário - agora denominado "arrendatário" - perdia direito à unidade habitacional obtida, que, assim, volta para a Caixa para ser de novamente comercializada sem perdas ou impedimentos.

A mercantilização da habitação popular, a transformação do financiamento habitacional num sistema sem riscos, a privatização de serviços públicos e a abertura ao comércio exterior permitiram, nos anos 1990, o surgimento de novas fontes de financiamento para a preservação do patrimônio e o surgimento de novos programas no plano federal.

\section{Características comuns e especificidades}

a) Quanto às premissas e objetivos

A parceria entre setor público e setor privado foi uma premissa compartilhada pelos programas gestados nos anos 1990, ainda que com diferentes concepções quanto ao conteúdo e ao sentido dessa cooperação. O PRONAC e o Monumenta foram os programas que se estruturaram, de modo mais orgânico, em torno dessa ideia, vista, no primeiro caso, como condição para a consolidação de um sistema permanente e democrático de financiamento da Cultura no país e, no segundo, como condição da conservação do patrimônio no longo prazo. No PRONAC a ação estatal isolada foi, inclusive, definida como nefasta, por conduzir ao dirigismo cultural e por impedir a participação ativa da sociedade na formulação e na execução da política pública. Na concepção que orientou a elaboraçãao do Monumenta, o aporte privado seria o que confere sustentabilidade aos processos de preservação, cabendo ao poder público liderar o processo de incentivo à ação privada e realizar os investimentos estratégicos iniciais. A participação da sociedade no financiamento da produção cultural e da conservação do patrimônio foi, portanto, um pressuposto essencial dos dois programas, cabendo ao Estado incentivá-la por todos os meios. 
No PRSH, a parceria entre Estado e sociedade também foi vista como essencial, mas o foco recaiu mais sobre o papel do poder público como formulador de políticas integradas voltadas para a inserção do patrimônio em processos de desenvolvimento urbano que contemplassem a melhoria do habitat e a diminuição do déficit habitacional. O Programa URBIS, de vida muito curta, tentou compatibilizar as premissas do PRSH e do Monumenta, estruturando em torno do conceito de reabilitação urbana uma proposta de aproveitamento do patrimônio como diferencial propulsor da dinamização econômica e como recurso para um desenvolvimento urbano sustentado.

Todos os programas estudados tiveram como objetivo a preservação do patrimônio cultural, com foco especial naquele protegido pelo Governo Federal. O PRONAC e o PRSH, entretanto, incorporaram uma visão mais abrangente, que se estende também ao patrimônio de interesse local e regional. O PRONAC foi o único programa de incentivo direto à produção cultural em sentido amplo.

Do ponto de vista dos seus objetivos e premissas, os programas dos anos 1990 constituíram tentativas de instituição de uma nova prática de atuação no campo cultural e preservacionista a partir da reunião de atores públicos e privados em torno de objetivos comuns. O valor social e econômico do patrimônio foi o liame dessa construção, que visou, em suma, a dividir e repassar, ainda que sem sucesso, a responsabilidade da preservação do patrimônio do Estado para o setor privado.

b) Quanto ao arranjo institucional, aos atores envolvidos e o seu papel

A maioria dos programas teve como principal ator o setor público. A participação do setor privado, apesar de muito enfatizada, se deu, na prática, de modo muito restrito, reduzido, e, em grande parte, prejudicado pela falta de instrumentos adequados para promovê-la. Os programas favorecem e focalizam, prioritariamente, o setor empresarial, em detrimento de pessoas físicas ou do investimento individual.

Embora a parceria setor público-setor privado tenha sido a pedra-de-toque ou meta fundamental de todos os programas estudados, apenas no PRONAC esta parceria ocorreu de modo efetivo e sistemático, ainda que totalmente 
desvinculado de uma política pública que lhe desse sentido global e social mais amplo. A participação do setor econômico no âmbito deste programa ocorreu por meio de um reduzido grupo de empresas estatais e corporações privadas que atuaram como proponentes e patrocinadores dos projetos financiados. Esses projetos, por sua vez, foram vinculados a produtores culturais consagrados nacionalmente, bem como aos interesses específicos de comunicação social, marketing e expansão de mercados dos patrocinadores. O determinador, portanto, dos rumos da política cultural financiada pelo Estado foi a indústria cultural do eixo Rio-São Paulo e a política de comunicação de grandes empresas. A Comissão Nacional de Incentivo à Cultura - CNIC, instância responsável pela coordenação e supervisão do PRONAC, perdeu, ao longo dos anos, importantes poderes deliberativos e não conseguiu abrir mais o leque do programa.

O setor privado deveria participar do Programa Monumenta pela mobilização de proprietários urbanos, da iniciativa privada e de organizações da sociedade civil. O papel desses atores na formulação e execução de ações foi considerado essencial, mas acabou sendo eventual e secundário. Embora colocada como eixo principal do programa, uma efetiva participação do setor privado pouco se verificou na prática.

No PRSH, os principais atores foram a Caixa Econômica Federal e o governo francês, o que o constituiu como mais um programa de coordenação também exclusivamente estatal. Tendo sido concebido, entretanto, como uma ação de articulação de parcerias, o PRSH buscou envolver vários atores públicos e privados - estes últimos, como executores de ações financiadas pelo programa ou como arrendatários. Assim, o PRSH foi o programa que mais privilegiou o investimento de pessoas físicas.

O Ministério da Cultura se caracterizou, na década de 1990, como a principal instância coordenadora e executora de programas, com participação central no PRONAC, no Programa Monumenta e no URBIS. Ao lado disso, constituiu outra grande novidade institucional do período a participação de parceiros internacionais no Monumenta e no PRSH. O BID e a UNESCO desempenham, em pé de igualdade com o MinC, papéis importantes na formulação, gerência e execução do Programa Monumenta, e o governo francês, por meio de alguns de seus ministérios, realizou a coordenação técnica do PRSH. 
Governos estaduais e municipais foram os principais atores locais na maioria dos programas, mas, em alguns deles, a terceirização foi a saída encontrada para as dificuldades de execução, diante da situação funcional precária da maioria dos seus organismos de preservação ou de obras públicas. No caso do Monumenta, por exemplo, a execução do programa foi realizada por estruturas executivas terceirizadas, tanto no plano central como no local. Em consequência, o programa canalizou grande parte dos seus recursos para a manutenção dessas estruturas, para o pagamento de consultorias e outras despesas administrativas, o que comprometeu, nessa fase, a execução de suas finalidades. No conjunto dos programas nacionais da área de cultura, o Monumenta foi o que mais se inseriu na estratégia do Governo Federal de terceirizar a execução de políticas públicas, com vistas a manter a aura de probidade administrativa e de controle do déficit público requeridos pela política de ajuste fiscal. Entretanto, ao invés de poupar, essa política foi uma fonte de desperdício e má administração dos parcos recursos mobilizados para investimento. Além disso, custou a precarização do aparelho de Estado e o enfraquecimento de diversas instituições públicas.

Ainda no plano institucional, uma novidade dos anos 1990, introduzida pelas intervenções locais e reforçada pelos programas nacionais, diz respeito à exclusão dos organismos públicos de preservação do patrimônio da formulação e coordenação das ações de preservação. Embora essas instituições tenham participado como parceiras da maioria dos programas, as funções centrais de formulação, coordenação e execução foram desempenhadas pelo Ministério da Cultura e pela Caixa Econômica Federal, no plano central, e por instâncias ligadas à execução de obras públicas, no plano local. Aos organismos de preservação foi reservada uma função burocrática, em geral restrita ao cumprimento de suas competências legais. No plano federal, é mesmo possível afirmar que os programas gestados nos anos 1990 marcaram um momento de declínio do IPHAN como protagonista da área de preservação, com a redução do seu papel à execução de tarefas circunscritas a questões de orientação e fiscalização. Os anos 1990 conferiram ao IPHAN um papel protocolar e de legitimação de projetos elaborados e executados, muitas vezes, à sua revelia, papel do qual a instituição não soube nem teve força política para se esquivar ou impor outra visão. Essa redução do papel da principal instituição de preservação do Brasil correspondeu, por outro lado, ao crescimento da importância 
institucional do Ministério da Cultura. Pode-se afirmar que, nos anos 1990, em consequência do crescimento das fontes de financiamento e da importância do patrimônio como instrumento de promoção política e institucional, o MinC e os governos estaduais e municipais assumiram o controle das ações de preservação.

c) Quanto aos recursos, instrumentos financeiros e incentivos

$O$ aporte de recursos externos e do setor privado foi a grande novidade dos programas de preservação dos anos 1990, e o PRONAC e o Monumenta foram os que mais avançaram nesse aspecto. O primeiro, por meio da tentativa de canalização de investimentos privados para projetos culturais, e o segundo, no que toca à captação de recursos externos. Cabe ressaltar, entretanto, que, embora estruturados com composição financeira mista, esses programas foram movidos, basicamente, por recursos públicos. No caso do PRONAC, em decorrência de o investimento privado se dar principalmente por meio do uso de renúncia fiscal. No Monumenta, porque os recursos privados previstos correspondiam a apenas $10 \%$ do montante total a ser movimentado.

No Programa Monumenta, os recursos previstos para o financiamento da conservação de imóveis privados correspondiam a cerca de 30\% do valor dos projetos locais, com aplicação limitada à execução de obras de estabilização estrutural, revisão de instalações e reparos no exterior dos imóveis. Esses recursos destinavam-se, originalmente, apenas a proprietários, na forma de empréstimos com juros subsidiados, mas não chegaram a despertar o seu interesse na primeira fase de execução desse programa.

O único programa que possuía linhas de financiamento de caráter permanente era o PRSH, pois operava por meio das carteiras de financiamento da CEF. Mesmo assim, como apontado anteriormente, essas linhas não eram adequadas aos projetos de reabilitação e não cobriam as várias situações fundiárias, de ocupação e relativas às características do patrimônio que compõem as áreas centrais de grandes cidades. Por essa razão, os recursos do PRSH tiveram que ser complementados com benefícios do PRONAC.

O grosso dos recursos com os quais os programas operaram se originou mesmo do setor público, sob a forma de aplicação do orçamento, empréstimo externo ou renúncia fiscal. O aporte privado foi incipiente. Mesmo no caso do 
PRONAC, no final da década de 1990, a proporção de recursos realmente privados aplicados em projetos culturais era de $35 \%$, contra $65 \%$ de recursos públicos. No âmbito do setor público, o Governo Federal e a União compareceram com a maioria dos recursos colocados à disposição dos programas nacionais, ficando a contrapartida estadual e local em torno de $20 \%$.

Os programas examinados foram, portanto, iniciativas de investimentos públicos na área de cultura e em patrimônio, via incentivos fiscais ou investimentos diretos. A parcela de recursos privados foi pequena e a destinada ao financiamento de pessoas físicas foi precária e não contou com instrumentos financeiros e um sistema de subsídios adequado.

d) Quanto aos mecanismos de planejamento, gestão e avaliação

Os programas estudados foram, de modo geral, muito pobres no que diz respeito a mecanismos de planejamento, programação, gestão e avaliação de ações. O PRONAC não instituiu instrumentos de planejamento para orientar a priorização de ações e, menos ainda, mecanismos de avaliação dos projetos executados. Essa falta, aliás, constituiu o calcanhar de Aquiles do programa e uma das principais fontes de críticas e solicitações de reformulação. Como visto, o PRONAC funcionou em consonância com uma demanda de projetos culturais extremamente concentrada em termos regionais e no tipo de projeto e de proponente. A ação dos principais patrocinadores não foi orientada para outras regiões, o que favoreceu sua concentração no eixo Rio-São Paulo, ou seja, na área de demanda cultural mais aquecida e de maior visibilidade nacional. O principal instrumento de gestão, a CNIC, desempenhou funções apenas consultivas e limitadas pela legislação.

O Programa Monumenta, por sua vez, teve nas "oficinas de planejamento" que ocorreram no início da montagem dos projetos locais o principal instrumento de programação e participação social. Essas oficinas, contudo, foram apenas workshops de identificação de ações que se desenvolveram sem o apoio de estudos ou diagnósticos mais aprofundados da situação urbana focalizada e não tiveram função de acompanhamento ou de gestão dos projetos executados. A Unidade Central de Gerenciamento e as Unidades Executoras de Projeto não constituíram tampouco mecanismos de gestão compartilhada, pois, embora com estrutura 
pesadamente terceirizada, não incorporaram representações da sociedade. No âmbito do Monumenta, os inventários e planos de preservação de sítios históricos constituíram ações exclusivas do componente correspondente ao fortalecimento institucional do IPHAN, sem vínculo ou relacionamento orgânico com os projetos locais. Estes foram definidos e executados independentemente da elaboração desses inventários e planos, que, inclusive, não foram previstos para todas as cidades participantes do programa. O Monumenta também não construiu instrumentos de avaliação dos processos deflagrados, exceto mecanismos burocráticos, como relatórios anuais e de progresso. Na fase de elaboração dos projetos locais eram exigidos estudos de impacto social e ambiental das intervenções projetadas, mas funcionaram mais como mecanismos de legitimação de projetos e intenções, não constituindo, portanto, instrumentos eficazes de avaliação pré e pós-operação.

$\mathrm{O}$ PRSH, no que toca aos instrumentos de planejamento e participação, padeceu de problemas semelhantes ao Monumenta. As "oficinas de planejamento participativo", realizadas no âmbito dos ateliês locais promovidos pelo programa, analogamente ao que ocorreu no Monumenta, não se apoiaram em estudos aprofundados e específicos de cada problemática urbana. O programa, entretanto, em algumas localidades, operou com equipes interinstitucionais que poderiam ter constituído importantes embriões para o desenvolvimento de ações integradas e concertadas, ao menos, no nível do poder público. O PRSH não estabeleceu a necessidade de elaboração de diagnósticos aprofundados ou planos que regulassem e programassem as ações nas áreas enfocadas, mas realizou experimentos de montagem de operações de reabilitação, que funcionaram como instrumentos de produção de conhecimento numa área em que o país não tinha muita experiência. O programa também não construiu instrumentos de gestão compartilhada com a sociedade, nem explicitou mecanismos de avaliação pós-operação.

Assim, no Brasil, os anos 1990 estiveram longe de constituir uma política de preservação e reabilitação urbana verdadeiramente estruturada e aparelhada. Os programas montados, em sua totalidade, ainda privilegiaram a execução de intervenções físicas, atuaram sem planejamento de ações no longo prazo e sem o conjunto de instrumentos necessários à implantação de ações mais eficazes e abrangentes. 
e) Quanto às ações previstas e aos modelos de intervenção

Na medida em que o interesse privado era atraído por ganhos de imagem, o PRONAC induziu à seleção de projetos de grande visibilidade e com boas possibilidades de repercussão na mídia e na opinião pública. Assim, no seu segmento "patrimônio cultural", verificou-se que a grande maioria das ações financiadas e executadas nos anos 1990 correspondeu a obras em grandes monumentos ou relacionadas a bens de excepcional valor artístico, localizados nos grandes centros urbanos e nas cidades históricas da região Sudeste. Essa concentração regional e temática foi acompanhada ainda de uma especialização crescente em termos de proponentes e patrocinadores. O funcionamento do PRONAC, portanto, não promoveu uma prática de investimentos individuais em favor do patrimônio, embora o programa tivesse dispositivos para tanto. ${ }^{9}$ Ao invés de propiciar, incentivar e difundir um uso social mais abrangente do patrimônio urbano, ou criar para este um mercado imobiliário mais dinâmico, o PRONAC favoreceu uma apropriação do patrimônio monumental como equipamento cultural de elite e instrumento de marketing empresarial.

As intervenções consideradas elegíveis no Programa Monumenta foram grandemente voltadas para a promoção do uso turístico e cultural nas Áreas de Projeto. Assim, os componentes do programa e suas ações correspondentes induziram ao tratamento dessas áreas como atrações urbanas nesta fase inicial, enfraquecendo sua apropriação como áreas de vivência da população e de localização de outros usos produtivos. As regras do programa não conduziam, ainda, os parceiros locais a abordar a área de intervenção a partir de uma problemática urbana ou patrimonial existente, o que levou, muitas vezes, a um determinismo funcional desvinculado das demandas e potencialidades locais.

Ao configurar-se como instrumento de articulação de parcerias e linha de financiamento especializada, o PRSH tendeu a adaptar-se aos modelos de intervenção dos programas aos quais se acoplava, não instituindo, propriamente, um modelo próprio. De todo modo, uma vez que se concentrava no financiamento da reabilitação de imóveis para uso habitacional, o programa surge como alternativa de utilização social mais abrangente do patrimônio urbano, com possibilidades, inclusive, de ampliar o alcance dos outros programas nacionais. Como comentado
9 Como visto no capítulo 5, pessoas físicas proprietárias de imóveis tombados pelo Governo Federal, por meio dos incentivos do PRONAC, poderiam abater do imposto de renda despesas com a restauração e conservação desses imóveis. 
no capítulo correspondente, o programa da Caixa implicou uma visão do patrimônio urbano inserido na questão da melhoria do habitat, da diminuição do déficit habitacional e da racionalização do crescimento e do uso do solo urbano. Partia-se, portanto, de uma concepção de intervenção urbana diversa, por exemplo, daquela do Programa Monumenta. Entretanto, em decorrência de seu caráter experimental e de sua natureza adaptável a demandas, o modelo de intervenção induzido pelo PRSH tendia a ser anulado ou diluído pelo de outros programas ou por questões localizadas. O programa incluía duas possibilidades: contribuir para deflagrar a implantação de uma verdadeira política nacional de reabilitação urbana, com instrumentos de planejamento, programáticos, financeiros e de gestão adequados; ou se transformar numa simples linha de financiamento, que funcionaria como reforço ou complementação de outros programas. Essa segunda possibilidade acabou sendo a mais viável.

Do ponto de vista das ações elegíveis e dos modelos de intervenção gerados, os programas implantados nos anos 1990 podem, portanto, ser divididos em duas correntes: a que favorecia um uso do patrimônio como atração urbana e instrumento de marketing; e a que buscava o seu uso social e vinculado a questões urbanas mais amplas. Em suma, o patrimônio urbano como media e commodity ou como elemento de política urbana e habitacional. Em decorrência de um maior vínculo com as forças políticas e econômicas dominantes, e do baixo nível de organização social do país, o modelo media/commodity foi o que prevaleceu e criou norma no período estudado. A falta de mercado nos segmentos mais abastados, contudo, foi o que manteve o modelo voltado para o desenvolvimento urbano e social na disputa pelos centros históricos das cidades estudadas.

\section{Resultados obtidos, avanços e retrocessos}

Considerando-se o nível incipiente de execução em que a maioria se encontrava nos anos 1990, os programas focalizados avançaram pouco com relação aos seus antecedentes dos anos 1970 e 1980. O PRONAC, por exemplo, pouco havia avançado com relação ao sistema instituído pela Lei Sarney, por falta de uma política que estabelecesse critérios de priorização e promovesse uma distribuição de benefícios fiscais mais equilibrada, do ponto de vista da regionalização e do 
tipo de projeto. Se o programa, com uma estrutura mais burocratizada, conseguiu sanear os problemas da antiga lei Sarney relativos à garantia do uso da renúncia fiscal apenas em projetos culturais, não resolveu o problema da concentração de patrocínios na região Sudeste e em determinados segmentos culturais e artísticos consagrados.

Já o Programa Monumenta não havia conseguido até 2003 mobilizar significativamente a iniciativa privada nas Áreas de Projeto, em função da pulverização de recursos, de um modelo de intervenção pouco adaptável aos problemas e demandas locais e da dificuldade para deslanchar o financiamento de imóveis privados. Assim, tudo indicava que o programa dificilmente implantaria o padrão de preservação sustentável pretendido, e, nesse aspecto, apesar de melhor concebido e estruturado, poderia não avançar muito com relação ao programa antecessor, o $\mathrm{PCH}$. No que toca, por exemplo, ao fortalecimento institucional dos vários atores públicos envolvidos, deveria avançar bem menos do que o seu antecessor dos anos 1970. A baixa internalização do programa nas estruturas permanentes do IPHAN e do MinC, em decorrência da sua estrutura organizacional terceirizada, indicava pouco aperfeiçoamento institucional. O Programa Monumenta teve, entretanto, o mérito de reintroduzir a questão da preservação urbana no plano nacional, impulsionando a formulação e a implantação de outros programas. Expôs, ainda, as carências técnicas e o despreparo do governo brasileiro neste campo, introduzindo um modelo de intervenção que, embora tivesse sido muito criticado, funcionou como referência para as outras políticas que foram montadas, como o URBIS e o PRSH.

Retrocessos e avanços são verificáveis de modo mais ou menos proporcional no âmbito do PRSH. Os avanços dizem respeito ao caráter mais permanente do novo programa, que, aparentemente, no começo dos anos 2000, teria mais apoio institucional e mais chances de consolidação do que o seu antecessor, o Programa de Recuperação e Revitalização de Núcleos Históricos do antigo BNH. Ganhos em conhecimento ocorreram a partir do desenvolvimento dos estudos de viabilidade de ações de reabilitação, em parceria com o governo francês e o BID, bem como das poucas operações concretizadas em Salvador, no Rio de Janeiro e em São Paulo. Nessas operações foram gerados importantes subsídios para a implantação de uma política nacional de financiamento da reabilitação imobiliária 
no país. O programa, contudo, pouco avançou no sentido da construção de uma carteira de financiamento específica para a reabilitação de imóveis históricos e da sua transformação numa atividade permanente e sistemática. Avançou pouco também na viabilização de operações de caráter social aliadas à preservação, pois a rigidez das suas linhas de financiamento não favoreceu esse desenvolvimento.

$O$ resultado mais negativo do PRSH se vinculou, de fato, aos limites e às regras das linhas de financiamento com as quais operava. Essas limitações induziram ao retalhamento e ao superaproveitamento de imóveis de valor patrimonial, o que obrigou o programa a atuar preferencialmente em ruínas, que permitiam mais liberdade de projeto. Ao fixar a área máxima da unidade habitacional financiada em $37 \mathrm{~m}^{2}$, o programa se chocava com os objetivos da preservação do patrimônio e trabalhava com uma visão de família de classe média baixa que não correspondia à realidade. Estudos já haviam demonstrado que, no Brasil, esse tipo de grupo familiar não era estável e tem grande necessidade de agregar espaço, o que, certamente, tornava difícil sua adaptação a unidades tão exíguas e sem possibilidade de ampliação. (MAGALHÃES, 2002) Entre os programas em andamento nas cidades estudadas, nos anos 1990, apenas o Novas Alternativas, do Rio de Janeiro, tinha, claramente, a preocupação de direcionar os projetos para famílias compostas por casais idosos ou sem filhos. Na medida, ainda, em que mecanismos de assistência social, educação patrimonial e acompanhamento pós-operação não estavam bem explicitados no escopo do programa, os resultados para a preservação patrimônio urbano chegaram a ser desastrosos.

Em termos conceituais, o Programa URBIS foi, sem dúvida, o que mais avançou em relação aos programas montados nos anos 1990, mas não teve resultados práticos suficientes para se consolidar. O URBIS ensaiou a implantação de uma política de reabilitação urbana inédita no país, ao propor uma estrutura de funcionamento baseada em mecanismos de planejamento participativo e programação, em instrumentos financeiros variados, em mecanismos de gestão compartilhada e num sistema permanente de avaliação. O programa, entretanto, não passou de uma carta de intenções, constituindo apenas uma promessa de transformação da prática em um embrião de política nacional, cujo modelo não gerou desdobramentos futuros. 
A participação da iniciativa privada foi, como visto, uma premissa fundamental de todos os programas iniciados nos anos 1990. Embora destinados a um papel de protagonistas, os atores privados se mantiveram como coadjuvantes pouco interessados no espetáculo da preservação urbana. Em geral, os parceiros privados permaneceram com uma postura passiva em relação aos processos deflagrados e aos projetos, ou, ainda, exibiram uma atitude de beneficiários expectantes. Essa atitude se relacionou à falta de crença no sucesso das intervenções empreendidas pelo poder público, à preferência por investimentos em setores e vetores de exploração imobiliária mais lucrativos e ao paternalismo que tradicionalmente caracterizou as políticas de preservação no país. Aos habitantes e ocupantes de imóveis nos sítios históricos coube, quase sempre, papel secundário. Sua visão como parceiros dos processos que se pretendia impulsionar não foi desenvolvida.

A estrutura dos programas e os atores que, efetivamente, mobilizaram mostram que a reabilitação do patrimônio urbano no Brasil, nos anos 1990, esteve presa à criação de empreendimentos e atrações urbanas e pouco vinculada à vida normal das cidades. Mostram, em suma, que a reabilitação do patrimônio não constituiu uma ação de caráter social, econômico e urbanístico mais amplo, e que, apesar dos avanços, ficou longe de se tornar um modo de urbanização importante. Seu caráter foi episódico, excepcional e extremamente vinculado à ação do Estado.

A execução dos novos programas nacionais de preservação, embora tenha sido incipiente, já mostrava claramente que a carência de instrumentos adequados de planejamento, de financiamento e de gestão reduzia, em muito, sua capacidade de transformação e reversão dos processos negativos instalados nas áreas históricas. Uma grande carência se localizava, sem dúvida, na falta de instrumentos de conhecimento da realidade patrimonial e urbana que permitissem montar diagnósticos consistentes e capazes de orientar o planejamento e a programação de ações significativas e sustentáveis. O grau de inter-relacionamento dos programas evidenciou seu caráter incompleto, mas era também o que lhes dava alguma chance de efetividade em face dos processos complexos que enfrentavam. Na medida em que o desenvolvimento do uso habitacional seria a ação de maior poder sobre esses processos, o PRSH ganhava, naturalmente, 
relevo maior. Embora pouco executado e carente de instrumentos adequados, o programa demonstrou seu potencial em Salvador e em São Paulo, assim como nas parcerias que estabeleceu com outros programas.

A criação dos programas dos anos 1990 como ações temporárias e a não implantação de uma política de reabilitação urbana de caráter permanente, interministerial e integrado é ainda o grande entrave a ser superado para que uma preservação duradoura e um aproveitamento socioeconômico do patrimônio urbano se tornem realidade no Brasil. Nenhum programa focalizado apresentou essas condições, mas, sem dúvida, todos contribuíram, em graus variados, para que essa necessidade ficasse evidente.

\section{As relações entre programas e intervenções}

A participação dos programas nacionais nas intervenções de recuperação, reabilitação e requalificação nas áreas centrais de Salvador, Rio de Janeiro e São Paulo foi pequena, considerando-se o período estudado. Contudo, trouxeram novos recursos para essas intervenções e possibilitaram sua continuidade. Em Salvador, por exemplo, a implantação do Programa Monumenta e do Projeto Rememorar, do PRSH, significou a retomada do Programa de Recuperação do Centro Histórico, que estava paralisado por falta de recursos.

Com ações em Salvador, no Rio de Janeiro e em São Paulo, o PRSH foi o programa que mais trouxe novos aportes aos processos locais instalados. O programa introduziu ou reforçou a questão habitacional, que estava posta de lado ou em segundo plano, ajudando a mantê-la, especialmente em São Paulo, no centro da cena. O poder de influência do programa esbarrou, entretanto, nos limites de suas próprias linhas de financiamento e nos diversos entraves que são interpostos ao desenvolvimento habitacional em áreas centrais.

O Programa Monumenta, por sua vez, se integrou com mais dificuldade nos projetos e processos em curso nas localidades pesquisadas, basicamente, em função do seu formato rígido. O programa ambicionava iniciar processos ou sanear processos existentes, reconduzindo-os para vias economicamente sustentáveis, mas, por atender a um número excessivo de sítios urbanos, a concretização 
dessa ambição tornou-se muito difícil. No caso de grandes metrópoles como Rio de Janeiro e São Paulo, os recursos do programa produziram parcos efeitos e agregaram apenas mais algumas intervenções. Ao lado disso, em decorrência do fato de que cada componente do programa implicava uma porcentagem fixa dos recursos totais, ações importantes - como as de desenvolvimento do uso habitacional no Rio de Janeiro e em São Paulo - não podiam utilizar a totalidade de seus aportes. Apenas em cidades pequenas o Monumenta parecia ter chances de produzir impactos mais significativos. Em Salvador, no entanto, sua inserção no programa estadual de recuperação do centro histórico foi positiva, pois encaminhou uma mudança de rumos importante.

O programa nacional com execução local mais expressiva nos anos 1990 foi o PRONAC. Seus mecanismos foram utilizados de modo intenso no Rio de Janeiro e em São Paulo, onde equipamentos culturais que aproveitaram imóveis antigos foram criados ou mantidos graças ao programa. Esses equipamentos funcionaram como importantes âncoras do processo de dinamização econômica e de atração de usuários de alta renda para os centros dessas duas cidades. Em áreas de dinâmica mais forte, como a Área Central de Negócios do Rio de Janeiro, os centros culturais funcionaram como agentes de substituição do perfil da ocupação, mas, em outras mais depreciadas, como a área da Luz, em São Paulo, promoveram apenas a formação de enclaves frequentados por públicos de alta renda.

\section{Sobre a importação de modelos}

Em muitas cidades do mundo desenvolvido, áreas esvaziadas e deterioradas pela obsolescência edilícia, pela fuga de funções e pela reestruturação do setor produtivo foram, a partir dos anos 1960, reincorporadas ao mercado por meio de empreendimentos habitacionais, comerciais, culturais e de lazer. Frequentemente fazendo apelo à preservação da memória e do patrimônio, essas intervenções - a maioria das quais localizadas em áreas centrais de grandes metrópoles lograram não somente a valorização imobiliária dessas áreas, mas também funcionaram como importantes instrumentos para alavancar ou melhorar sua inserção em circuitos internacionais de comércio, turismo e entretenimento. Esta fórmula 
de sucesso, inventada pelos americanos, se apoia basicamente em dois pilares: na identificação de uma nova função estratégica para o lugar esvaziado, compatível com o contexto urbano e regional existente, e na deflagração de uma operação de reurbanização consorciada entre poder público e setor privado.

Em torno desse projeto comum, a operação de reincorporação da área ao mercado se produz, normalmente, pela promoção de alterações no regime de uso e ocupação do solo, por uma eventual redução de taxas e impostos para os investidores, e pela reciclagem de estruturas antigas, acompanhada da inserção, no lugar, de novos objetos arquitetônicos ou artísticos que funcionam como atração e ajudam a divulgar o empreendimento urbano, nacional e internacionalmente. Essas intervenções constituem, em suma, operações de criação de novas atrações urbanas e novas fronteiras de produção imobiliária, cujo objetivo é transformar áreas que estavam à margem da dinâmica imobiliária e econômica das cidades em setores cobiçados. O resultado dessas intervenções é, quase sempre, a deflagração de um processo de valorização, com o correspondente afastamento de atividades menos rentáveis, assim como de antigos usuários e ocupantes. A cultura e a história desempenham, nesses processos, importantes papéis de legitimação, produção de significados e de valor agregado.

Com maior ou menor ancoragem no patrimônio e em recursos privados, essa fórmula foi reproduzida em várias cidades, constituindo mesmo o grande modelo de intervenção urbana na contemporaneidade. Ele trouxe para o campo do urbano e para o domínio do público uma lógica empresarial típica de empreendimentos privados. O sucesso dessas intervenções, entretanto, não se deveu apenas isso, mas a um conjunto de fatores. Entre estes, destacam-se um bom grau de desenvolvimento econômico - em termos de bons níveis de reprodução e de renda da população com produção de excedente financeiro e disponibilidade de investimentos; fortes mercados internos; e, ainda, o equacionamento de questões básicas relativas a moradia, saúde e educação, pois são fatores que fornecem o lastro necessário ao desenvolvimento pleno de atividades como o turismo e o entretenimento. Assim, a concretização de inversões privadas de monta, e um contexto geral de desenvolvimento econômico, urbano e social, fornecem o solo sobre o qual se assentam esses empreendimentos urbanos - o que garante, em última análise, o seu sucesso. É esse solo, justamente, o que falta nos países menos desenvolvidos. 
Esse modelo, entretanto, foi largamente transportado para países em desenvolvimento e, durante os anos 1990, "vendido" por grupos estrangeiros de consultoria e agências de financiamento como a panaceia capaz de reverter não somente processos de decadência de setores urbanos, mas, até mesmo, a crise econômica de cidades. A transformação se realizaria pelo poder que essas intervenções urbanísticas teriam de gerar e potencializar vantagens comparativas, as quais possibilitariam às cidades em crise competir por uma posição importante no seleto grupo das metrópoles globais ou plugar-se com eficiência em alguma rede ou circuito da economia globalizada. Embora as estratégias utilizadas fossem as mesmas dos países centrais, o desenvolvimento do modelo em contextos urbanos de países periféricos produziu resultados inócuos, parciais ou incompletos, nos anos 1990, e ganhou contornos específicos, relacionados às características de desenvolvimento econômico, político e social de cada lugar em que foi aplicado.

Diferentemente do que ocorreu em países desenvolvidos - onde, muitas vezes, a própria iniciativa privada tomou a dianteira -, nos países periféricos, os governos promovem esses projetos sozinhos, e encontram muita dificuldade para atrair parceiros privados dispostos a fazer investimentos significativos. Estes se materializam apenas quando pesadamente incentivados ou subsidiados, o que tem gerado relações público-privadas desequilibradas, concentradoras de riquezas e, em geral, favorecedoras do mero oportunismo. Observa-se, a partir das experiências brasileiras estudadas nesse trabalho, que essa assimetria tende a aumentar em contextos políticos oligárquicos ou onde a organização social é precária. Esse desequilíbrio tem gerado tanto situações de falta de compromisso por parte do setor privado com intervenções iniciadas quanto dificuldades para que projetos saiam do papel por falta das inversões privadas complementares. Outras dificuldades de funcionamento em contextos periféricos se relacionam ao fato de que, diferentemente do que predomina nos países centrais, o patrimônio urbano - apesar de inserido em estratégias de aproveitamento econômico há muito tempo - não alcançou ainda, nesses contextos, grande valor de mercado. Ao lado disso, a prática de preservação do tecido urbano existente ainda é muito restrita a certas áreas das cidades e não tem grande importância em sua gestão. Como visto em capítulos precedentes, nas grandes cidades brasileiras os investimentos imobiliários mantêm um perfil essencialmente ancorado na produção 
de novos empreendimentos localizados nos vetores de concentração de uma ocupação de classe média alta, fora das áreas de consolidação mais antiga. A reciclagem e a reforma são operações ainda marginais nesse mercado, assim como no âmbito de nossa construção civil.

Mesmo assim, ainda que em graus variados, todas as maiores cidades brasileiras tentaram, nos anos 1990, desenvolver modelos de intervenção dentro dessa lógica e sonharam se tornar, num passe de mágica urbana, novas Barcelona, Bilbao, Lisboa ou Nova York - ou ter, ao menos, sua versão local de Harbour Place. Para tanto, despenderam grandes somas em projetos e consultorias especializadas, desistindo de aperfeiçoar, em alguns casos, modelos locais já estruturados. Apostaram, enfim, em estratégias vinculadas a demandas inexistentes ou artificiais, que implicaram o abandono ou a colocação em segundo plano de projetos ligados ao atendimento de demandas reais. Uma das principais dificuldades de reprodução do modelo dos países desenvolvidos no Brasil tem sido, portanto, a falta de demanda configurada que atraia investimentos privados, o que tem feito com que essas intervenções se viabilizem apenas parcialmente e às custas de recursos públicos.

No mundo desenvolvido, a promoção, pelo Estado, de uma nova fronteira imobiliária em áreas centrais ou em bairros antigos repercute positivamente numa iniciativa privada sedenta por associar ações, marcas e produtos à cultura e ao patrimônio. Repercute, ainda, num amplo mercado que consome bens culturais sob todas as formas e num território já densamente ocupado e com poucas possibilidades de expansão. O caminho "natural" dos investimentos é, portanto, reciclar imóveis e áreas urbanizadas. Nossa realidade é diferente, e faríamos bem em olhá-la mais amplamente ao pensar o repovoamento de áreas centrais. A demanda que temos claramente configurada é de outra natureza e está vinculada a um público diferente daquele que sustenta o tipo de empreendimento urbano produzido por esse modo de intervenção. Assim, para que ações de requalificação, intensificação do uso e dinamização de setores esvaziados e deteriorados tenham sucesso em nosso contexto, é necessário que se vinculem à dinâmica da área focalizada, ampliando-a e dando-lhe melhores condições de desenvolvimento, ou atendam a demandas reais que estão colocadas. Sem isso, os investimentos não produzem os efeitos esperados. 
Os anos 1990 marcaram, no Brasil, o crescimento da influência dos modelos norte-americanos de financiamento da cultura e de intervenções urbanas, mas marcaram também, com as experiências que foram executadas ou propostas, a formação de uma consciência relativa à sua pouca eficácia frente aos quadros sociais, econômicos e urbanos de nossas cidades. Essas iniciativas ilustram, ainda, as tentativas do poder público de se aproximar de novos paradigmas, com vistas a diminuir a influência do modelo de intervenção estatal pura que sempre dominou nossa prática governamental, sempre favoreceu interesses localizados e pouco solucionou problemas. O desenvolvimento desse aspecto positivo, entretanto, foi prejudicado nas intenções e programas estudados por uma avaliação equivocada das potencialidades de nossas áreas centrais e por uma opção generalizada por um caminho aparentemente mais fácil em direção ao sucesso. Nessa quimera, recursos foram desperdiçados e muitas energias foram perdidas. 